\title{
Women in Patriarchy: A Study of Sexual Colonialism in Colleen McCullough's The Thorn Birds
}

\author{
Dr. Deepali Sharma
}

Assistant Professor-III

Amity University

Noida, Uttar Pradesh, India

sharmadeepali390@gmail.com

\section{Abstract}

Colleen McCullough, a famous Australian women novelist, extensively deals with the issue of sexual colonization by exhibiting the fact that this world belongs to men not to women where women suffer and men cause them pain. Meggie, the central character in the novel is shown as the victim, sufferer and the colonized individual and Paddy, Ralph and Luke are shown as the epitome of the British colonizers who misused, misbehaved and degraded the women during their colonial rule. The novelist while sketching women characters does not asseverate as ostensible women of letters but for the delineation of patriarchy in the novel The Thorn Birds which clearly manifests her declivity in the vicinity of the infringement with women in Australian society. .

Keywords: Patriarchy, Colonization, Gender, Suffering, Tradition.

"We create our own thorns, and never stop to count the cost. All we can do is suffer the pain, and tell ourselves it was well worth it".

Since ages women have been struggling to create their space in the world belonged to men. The voice of women, however strong it maybe, can never be heard because they are the weaker sex. Colleen McCullough, an Australian female novelist, furnishes the concept of 
patriarchy in her novel The Thorn Birds. McCullough was investigated for the diversification and rectitude in her works. She does not asseverate as ostensible women of letters but for the delineation of patriarchy in the novel The Thorn Birds, clearly manifests her declivity in the vicinity of the infringement with women in Australian society. The novel to a great extent denigrates the mighty anatomy of patriarchy at variegated magnitude and at disparate gradation where women have no say. Men are at the center of the universe and women are at the margin. Women are the other, the colonized and men are the colonizer. Men are for the public phenomenon and women for the private entanglement. Patriarchy, verbatim adjudicates by men.

There are several reasons of this power structure of patriarchy in any society. It is when men possess power over women whether the power is exercised through the legal system, through the force of custom, or through women acceptance of her inferiority. It is specifically elaborated by the novelist that the power structure of patriarchy in a social milieu, justifies its intentions by being impartial towards women. This type of a social milieu is completely disinterested in the growth and development of women at large. There is a common perception among the people in the novel to consider women as the representatives of their culture and tradition in the wide social milieu. They are not treated as a human being with flesh and blood but burdened with the responsibilities of womanhood. Contemplating the same cogitation, though, in a different culture and with different beliefs, the novel The Thorn Birds, outlines the lives and stories of the women of Cleary family, mainly the life of Meggie, the protagonist of the novel.

McCullough extensively deals with the issue of sexual colonization by exhibiting the fact that this world belongs to men not to women.This is the world where women suffer and men cause them pain. Meggie is shown as the sufferer and Paddy, Ralph and Luke are shown as the colonizers. As we know, sexual colonialism clearly demonstrates the alliance between 
the sexes, an association of dominance and subservience. It refers to the relationship between sex and power. The power remains in the hands of men who are highly ambitious whether it Paddy, the father of Meggie, Ralph, her love or Luke O'Neill, her husband. All men are shown as extremely ambitious and greedy for power. The novel uncovers not only the story of Meggie but also represents the entire Australian society's treatment with women at large. As Simone de Beauvoir perceives it, "the position that women occupy in the society is comparable in many respects to that of racial minorities in spite of the fact that women constitute numerically at least half of the human race.” (9)

The Thorn Birds, is McCullough's second published, though her first planned novel. The novel was the biggest success in the literary arena. Published in 1977, it propelled her into the category of the renowned writers. Colleen McCullough, is usually thought of as an Australian writer, she has lived most of her adult life outside Australia and in fact, has made it a primary setting for only a few of her novels, including The Thorn Birds, the novel credited into a biggest success and she got immense fame after its publication. She has written for an American and then an international reading public rather than for the Australia of her own background. Reason being, she lived most of her life outside Australia. The novel projects the idea that woman's life is completely dependent upon men. Very similar to the ideas criticized by the first wave western feminist Mary Wollstonecraft in her work, The Vindication of the Rights of Women. She discussed how the girl child is from the beginning is made to believe that her chief motive in the life is to get married and to have children. Brought up with this traditional mindset, Meggie, the only daughter in the Cleary family, develops the goal of domesticity. Meggie has no other ambition but to get married, to have children and to have a home of her own. The father, Paddy Cleary is a dominating one, who has segregated everyone's duties in the household on the basis of their sex. In the words of Colleen McCullough, "the most stringent rule in Paddy's domain concerned the proper 
delegation of duties. The house was woman's work, and that was that. No male member of the family was to put his hand to a female task." (TB, 15)The girl has to be in the house to do domestic chores and boys have to be in the field. Meggie, being brought up into a patriarchal family where the entire importance was given to the boys and not to the girls. Her mother, Fee always thinks and cares about the wellbeing of her sons because they will carry the family name, "Fee knew what her lot would be, and did not envy her. The boys were different; they were miracles, males alchemized out of her female body. It was hard not having help around the house, but it was worth it." (TB, 18)The parents are of the view that boys have to get education because the money spent on them is like a fixed deposit which will come back to the family. The childhood notions of love and affection are not to be seen among the siblings also. When Meggie is given the doll as a gift by her parents, the brothers snatch the doll and tear it into pieces. The happiness is checked and controlled at every moment and Meggie has no other option but to cry because she is the victimizer who has to suffer silently and the brothers are the colonizers who cannot tolerate their subordinate to feel happy.

Patriarchy not only restricts the growth and development of the girl child but it also affects the lives of the boys in the negative manner. The Cleary brothers are satisfied amongst each other. They do not like the company of any girl. Consequently, they fail in their love relationships also. On the other hand, Meggie develops herself into a low esteemed individual who has to bear the burden of her womanhood. Paddy, her father is like a colonizer who does not allow any freedom to his daughter. It somehow restricts her growth as an individual. He says, "we're working-class people, which means we don't get rich or have maids. Be content with what you are and what you have." (Thorn Birds) She can't go outside alone but has to be accompanied by any of her brother. 
The freedom and liberty which Meggie does not have in her father's house, she often thinks of achieving it after marriage. In the novel, marriage is shown as an institution, another form of subjugation. Meggie falls in love with Ralph de Bricassart, a priest in the Church. Ralph is highly impressed by the charm and beauty of Meggie. He falls in love with her but his love for the Church is more important than the love for Meggie. He says, “it's years of life, even before getting to the point of ordination. The careful development of a state of mind which opens the vessel to God. It's earned! Every day it's earned. Which is the purpose of the vows, don't you see? That no earthly things come between the priest and his state of mind not love of a woman, nor love of money, nor unwillingness to obey the dictates of other men." (TB, 60)

The novelist has clearly shown that men and women opt for relationships for their own selfish motives. Love is not the only concern but there are more factors to get married. Ralph is a priest so he cannot marry Meggie though he loves her. His ambition to become the Cardinal is more important than Meggie. As McCullough points out in The Thorn Birds, "that no earthly things come between the priest and his state of mind - not love of a woman, nor love of money, nor unwillingness to obey the dictates of other men." (69)

The novelist also highlights that there are different worlds belong to men where there is place for a woman. Women are not allowed to enter into the worlds belong to men. Men are happier in the company of men and they treat women only as a sexual object and nothing else. Gwen Morris aptly remarks, "Relations between men and women are seen as a constant battle for power. Women succeed through subterfuge. Both Fee and Meggie consider they had tricked their lovers by having a permanent part of them-their children." ( ) Meggie marries Luke O'Neill, thinking that Luke's face is very similar to that of Ralph. But Luke is another colonizer who is only interested in the money Meggie has. The marriage between Luke and Meggie is a failure from the very beginning itself. Meggie suffers silently without 
saying anything to her husband because a wife's life is nothing without her husband and this notion of patriarchy is so much ingrained in her mind that she does not think of asking anything to her husband but silently suffers. The failure in the marriage leads Meggie to develop extra marital relationship with Ralph. She secretly meets her lover Ralph and gives birth to his son Dane.

McCullough, though does not speak loudly as a feminist but her portrayal of womanhood shows her as a feminist. She says in the novel, "if you love people, they kill you. If you need people, they kill you. They do I tell you!'(TB) She also states that an unhappy wife cannot prove to be a successful mother. When Meggie becomes the mother, she also showers her love and affection to her son Dane and not to her daughter Justine. She repeats the same behavior which she faced in her childhood. The novel demonstrates the repercussions of patriarchy by excluding women on the basis of their sex which is biological and no one has control over it. The novelist has shown that Australian society imposes many restrictions on women to participate equally with men. Women are not allowed to occupy any prestigious position in the Roman Catholic Hierarchy, which is another institution to favour sexual colonialism. Meggie sees God as her enemy. She says, "God rot God, I say! God the sod! The utmost enemy of women, that's what God is." (425, TB) The treatment towards women is that of a subordinate. Women help men in every work. Fee not only helps Paddy in the field but performs more than him but when it comes to celebrate the hard work than Paddy celebrates his success with other male members only. Among male labourers there is no space for women. There is a complete exclusion of women.Gwen Morris observes "the women in the novel are capable of doing "men's work"-Meggie is a good stockman, and Fee successfully manages the property after Paddy dies but they see themselves as weak" (TB, 63) 
Colleen McCullough represents the true picture of a patriarchal society where women have nothing to say. They are treated as servants. The novel is true picture of a working class society. 


\section{Works Cited}

K. Balachandran. (2010). Critical Essays on Australian Literature. Arise Publishers \& Distributors. New Delhi.

R.K. Dhawan, David Kerr. (1993). Australian Literature Today.Indian Society for Commonwealth Studies. New Delhi.

Arneil, Barbara.(1999).Politics \& Feminism. Oxford: Blackwell Publishers Ltd. 1-256

De Beauvoir, Simone. (1987). The Second Sex.New York: Penguin Books.

McCullough, Colleen. (2005). The Thorn Birds. New York: Harper Collins Publishers.

Web Links:

Gwen Morris, “An Australian Ingredient in American Soap: The Thorn Birds by Colleen McCullough”. Onlinelibrary.wiley.com 